\title{
UPAYA MENINGKATKAN KETERAMPILAN BERBICARA DENGAN MEDIA MENYEBUT GAMBAR PADA SISWA KELAS VI SD NEGERI KAHURIPAN BANTARKALONG TASIKMALAYA TAHUN 2010/2011
}

\author{
Oleh: Anwar Sanusi, S.Pd.
}

\begin{abstract}
Class action research (PTK) this is a form of collaborative research on scientific actions in the form of an effort improve speaking skills on the students of classes VI SD Negeri Kahuripan Bantarkalong with media mentions the image and at the same time efforts to improve language learning teachers in Indonesia. PTK is carried out in SD Negeri Kahuripan Bantarkalong, class VI Lessons Year 2010/2011, with the number of students is 35 children, the result looks a pretty meaningful increase on the process and results. Process improvement can be seen from the increased activeness of students. Improvement of the results can be seen from the increase in the average score action performed before and after done action. On a number of pretes average score obtained student 12.9. The average value of 65. II the number of cycles on the average score obtained 15.7 students. The average value of 78. The increase in the number of average score on the initial tests of silus II as much as 2.8 or amounting to $22 \%$. Thus can be drawn the conclusion that the Act is applied using the media mentions images can improve speaking skills can improve the performance of students and teachers in learning Indonesian Language.
\end{abstract}

Keywords: speaking skills, media mentions pictures

\begin{abstract}
ABSTRAK
Penelitian Tindakan Kelas (PTK) kolaboratif ini merupakan suatu bentuk penelitian tindakan ilmiah yang berupa suatu upaya meningkatkan keterampilan berbicara pada siswa Kelas VI SD Negeri Kahuripan Bantarkalong dengan media menyebut gambar dan sekaligus upaya untuk meningkatkan kinerja guru dalam pembelajaran bahasa Indonesia. PTK ini dilaksanakan di SD Negeri Kahuripan Bantarkalong, Kelas VI Tahun Pelajaran 2010/2011, dengan jumlah siswa 35 anak, Hasilnya terlihat adanya peningkatan yang cukup berarti pada proses dan hasil. Peningkatan proses dapat dilihat dari peningkatan keaktifan siswa. Peningkatan hasil dapat dilihat dari peningkatan skor rata-rata sebelum dilakukan tindakan dan setelah dilakukan tindakan. Pada pretes jumlah skor rata- rata yang diperoleh siswa 12,9. Nilai rata-rata 65. Pada siklus II jumlah skor rata-rata yang diperoleh siswa 15,7. Nilai ratarata 78. Peningkatan jumlah skor rata-rata pada silus II dari tes awal sebanyak 2,8 atau sebesar 22\%. Dengan demikian dapat ditarik kesimpulan bahwa tindakan yang diterapkan yakni menggunakan media menyebut gambar dapat meningkatkan keterampilan berbicara siswa dan dapat meningkatkan kinerja guru dalam pembelajaran Bahasa Indonesia.

Kata kunci: keterampilan berbicara, media menyebut gambar
\end{abstract}

\section{PENDAHULUAN}

Pembelajaran yang bermakna adalah pembelajaran yang bermanfaat bagi para siswa untuk bekal hidupnya. Dengan demikian, pembelajaran bahasa Indonesia diharapkan dapat membekali siswa dengan beberapa keterampilan yang bermanfaat.

Dalam pembelajaran bahasa Indonesia ada empat aspek keterampilan berbahasa. Aspek tersebut meliputi mendengarkan, berbicara, membaca, dan menulis. Berbicara merupakan salah satu aspek keterampilan berbahasa. Tarigan (1985:15) menjelaskan bahwa tujuan utama berbicara adalah berkomunikasi. Agar dapat menyampaikan pesan secara efektif, maka 
sebaiknya pembicara memahami makna segala sesuatu yang ingin dikomunikasikan. Keterampilan berkomunikasi secara lisan dapat dicapai melalui pembelajaran kompetensi berbicara.

Kriteria ketuntasan minimal suatu kompetensi dasar yang ideal adalah 75. Artinya setiap siswa harus mencapai nilai minimal 75. Sementara itu, kriteria ketuntasan dalam kelas harus mencapai $85 \%$. Jika jumlah siswa dalam satu kelas 35 orang, idealnya 30 orang yang mencapai nilai minimal 75.

Kenyataan yang ada pada siswa Kelas VI SD Negeri Kahuripan Bantarkalong pada survey awal, berdasarkan wawancara dengan guru kelas VI serta pengamatan langsung pada saat pembelajaran dapat diketahui bahwa keterampilan berbicara siswa belum maksimal. Ketika berbicara siswa masih mengalami permasalahan. Siswa kurang konsentrasi, pilihan kata kurang tepat, pelafalan, pengaturan jeda, intonasi, keras/lemah suara, cepat/lambat berbicara, ekspresi wajah, gerak/mimik yang belum sesuai. Kurang maksimalnya kemampuan berbicara siswa dipengaruhi oleh beberapa hal yaitu (1) kurangnya motivasi, (2) kurangnya media pembelajaran, dan (3) kurang tersedianya sarana prasana yang memadai.

Untuk mengantisipasi hal tersebut, dibutuhkan strategi yang tepat sehingga siswa lebih aktif dan bersemangat dalam mengikuti kegiatan belajar sehingga kegiatan belajar di kelas dapat berlangsung aktif, inova ${ }^{+i f}$ kreatif, dan menyenangkan. Dengan kondisi yang demikian itu diharapkan kemampuan. 1 a akan lebih meningkat.

Strategi bercerita dengan media menyebut gambar dapat digunakan dalam pembelajaran berbicara. Strategi ini diharapkan dapat memudahkan siswa untuk menggali ide sebagai bahan bercerita. Dengan strategi ini siswa diharapkan akan lebih aktif dan kreatif serta lancar berbicara. Oleh sebab itu, bersama kolaborator akan diadakan penelitian dengan judul "Upaya Meningkatkan Keterampilan Berbicara dengan Media Menyebut Gambar pada Siswa Kelas VI SD Negeri Kahuripan Bantarkalong Tasikmalaya"

\section{RUMUSAN MASALAH}

Berdasarkan batasan masalah di atas dapat dirumuskan masalah yaitu "Apakah media menyebut gambar dapat meningkatkan keterampilan berbicara siswa Kelas VI SD Negeri Kahuripan Bantarkalong?”

\section{TUJUAN PENELITIAN}

Bertolak dari rumusan masalah, tujuan yang akan dicapai dalam penelitian ini adalah upaya meningkatkan keterampilan berbicara dengan media menyebut gambar.

\section{METODE PENELITIAN}

Penelitian yang akan dilakukan adalah penelitian tindakan kelas dengan melibatkan mahasiswa sebagai peneliti dan guru Bahasa dan Sastra Indonesia sebagai kolaborator. Ragam desain yang diajukan adalah desain Action research model Kemmis dan Mc Taggart. Konsep pokok penelitian tindakan kelas (PTK) model Kemmis dan MC Taggart terdiri dari empat komponen, yaitu (a) perencanaan (planning), (b) tindakan (acting), (c) pengamatan (observasing), dan (d) refleksi (reflecting).

Penelitian dilaksanakan di SD Negeri Kahuripan Bantarkalong Tasikmalaya. Adapun subjek penelitiannya adalah siswa Kelas VI SD Negeri Kahuripan Bantarkalong Tasikmalaya tahun pelajaran 2010/2011 semester dua dengan jumlah siswa 35 anak, terdiri dari 18 lakilaki dan 17 perempuan. 
Instrument penelitian meliputi angket, catatan lapangan, pedoman pengamatan, dan lembar penilaian menceritakan tokoh idola. Analisis data penelitian ini mencakup proses dan hasil tindakan. Analisis tindakan dilakukan secara kualitatif, dan analisis hasil tindakan dilakukan secara kuantitatif. Analisis kualitatif dilakukan dengan kolaborasi pada saat dilakukan refleksi yang didasarkan dari data yang terkumpul. Analisis kuantitatif dilakukan untuk menganalisis data yang berupa skor, yaitu hasil penilaian keterampilan berbicara dengan media gambar. Dari setiap siklus diperoleh skor tiap-tiap siswa, yang kemudian dicari ratarata skornya. Dengan membandingkan rata-rata skor siswa pada tes awal, siklus pertama, dan siklus kedua dapat dilihat peningkatan yang terjadi. Data yang sudah diperoleh dicari keabsahannya, sehingga dapat diper-tanggungjawabkan. Teknik keabsahan data yang digunakan adalah tanya jawab dan trianggulasi. Keberhasilan penelitian tindakan kelas ditandai dengan adanya perubahan menuju ke arah perbaikan atau peningkatan. Indikator keberhasilan penelitian tindakan kelas ini dikelompokkan ke dalam dua aspek, yaitu indikator keberhasilan proses dan indikator keberhasilan hasil. Indikator keberhasilan proses mencakup seluruh atau setidak-tidaknya sebagian besar $(75 \%)$ peserta didik terlibat secara aktif, baik fisik, mental, maupun sosial dalam proses pembelajaran. Indikator keberhasilan hasil mencakup seluruh atau setidak-tidaknya sebagaian besar (75\%) peserta didik telah mencapai Kriteria Ketuntasan Minimal (KKM) yang telah ditetapkan (75)

\section{HASIL PENELITIAN \\ Hasil Penelitian}

Dalam penelitian tindakan kelas ini digunakan media menyebut gambar, yaitu gambar- gambar tokoh baik itu pahlawan, olahragawan, penyanyi, dan pemain film. Penelitian tindakan kelas ini dilaksanakan secara bertahap. Kegiatan dimulai dengan mencari informasi awal tentang pembelajaran menceritakan tokoh idola, dengan menyebarkan angket dan melakukan tes awal sebagai alat ukur yang nantinya akan digunakan sebagai pembanding dengan tes setelah dilakukan serangkaian tindakan.

\section{Informasi Awal Pengetahuan dan Keterampilan Siswa dalam Bercerita}

Informasi awal pengetahuan dan pengalaman siswa dalam bercerita dapat dilihat dari angket yang diberikan kepada siswa sebelum dilaksanakan tindkan kelas. Angket tersebut terdiri dari Sembilan butir pertanyaan pilihan ganda. Selain melalui angket, informasi awal keterampilan siswa dalam bercerita juga diperoleh dari kegiatan tes awal sebelum dilakukan tindakan. Pada tahap ini, siswa diberi tugas untuk menceritakan tokoh idola dengan menyebutkan identitas tokoh, keunggulan tokoh, serta alasan mengidolakannya dengan bahasa yang sesuai, lafal yang jelas, pilihan kata yang tepat, jeda, intonasi, volume, serta ekspresi yang sesuai. Masing- masing siswa diberi kebebasan untuk memilih tokoh yang diceritakan.

Waktu dua jam pelajaran yang diberikan oleh guru pada saat tes awal tidak dipergunakan secara maksimal oleh siswa. Banyak siswa yang menceritakan tokoh idola kurang sungguh- sungguh. Banyak siswa hanya menyebutkan nama tokoh dan profesinya saja. Mayoritas siswa masih belum maksimal dalam bercerita. Masih ada siswa melafalkan kata kurang jelas, jeda, intonasi monoton, bahkan ada siswa yang volume suaranya hampir tidak terdengar, serta mayoritas siswa bercerita kurang ekspresi yang sesuai.

Berdasarkan hasil tes awal keterampilan menceritakan tokoh idola, dapat diperoleh informasi mengenai skor rata-rata pada setiap aspek dan kriteria berikut ini.

\section{a. Aspek Kelengkapan Isi}

Aspek kelengkapan isi meliputi tiga kriteria yaitu identitas tokoh, keunggulan, dan alasan mengidolakan. Skor rata-rata yang diperoleh 2,7. Nilai rata-rata yang diperoleh siswa 66. Hal ini menunjukkan bahwa bahwa keterampilan menceritakan tokoh idola aspek kelengkapan isi masih kurang karena di bawah ketuntasan yang ditetapkan yaitu 75. 


\section{b. Aspek Pilihan Kata}

Aspek pilihan kata yang dimaksudkan disini adalah penggunaan pilihan kata yang sudah sesuai. Pada aspek ini diperoleh skor rata-rata 2,8 dengan nilai rata-rata 69. Hasil ini menunjukkan bahwa sebagian besar siswa telah penggunaan pilihan kata dengan baik.

\section{c. Pelafalan}

Skor rata-rata pada aspek pelafalan yang diperoleh siswa 2,5 dengan nilai rata-rata 63. Banyak siswa yang melafalkan kata kurang jelas dan kurang tepat.

\section{d. Jeda dan Intonasi}

Pengaturan jeda dan intonasi termasuk di dalamnya keras/ lemah suara, dan cepat / lambat bercerita. Pada aspek ini jumlah skor rata-rata yang diperoleh siswa 2,6. Nilai rata-rata 66. Hasil ini menunjukkan bahwa kemampuan siswa dalam menceritakan tokoh idola untuk aspek jeda dan intonasi masih perlu ditingkatkan.

\section{e. Gerak/mimik}

Apek gerak/ mimik yang dimaksudkan adalah kesesuaian ekspresi wajah, gerak, sikap, ucapan dengan isi cerita. Pada aspek ini skor rata-rata yang diperoleh siswa adalah 2,3 dengan nilai rata-rata 59. Hasil itu menengarai bahwa siswa belum mampu berekspresi dalam memnceritakan tokoh idola.

Berdasarkan angket awal dan hasil tes awal menceritakan tokoh idola, dapat disimpulkan bahwa selama ini pembelajaran menceritakan tokoh idola belum maksimal. Pembelajaran bercerita masih kurang, minat serta kemampuan siswa dalam menceritakan tokoh idola masih belum memadai.

\section{Pelaksanaan Tindakan Kelas}

Pelaksanaan tindakan kelas yang berjudul Upaya Meningkatkan Keterampilan Berbicara dengan Media menybut Gambar pada Siswa Kelas VI SD Negeri Kahuripan Bantarkalong ini dilakukan dalam dua siklus, selama kurang lebih satu bulan. Jadwal pelaksanaan tindakan diatur dengan diskusi bersama guru kelas VI selaku kolaborator yaitu Ibu Nunung Rohaeti, S.Pd. Dalam penelitian ini peneliti bertindak sebagai guru. Pelaksanaan penelitian tindakan kelas pada Siklus pertama dan kedua akan dideskripsikan berikut ini.

\section{a. Siklus Pertama}

\section{1) Perencanaan}

Peneliti yang sekaligus guru merancang rencana pembelajaran menceritakan tokoh idola dengan media menyebut gambar, menyiapkan gambar dan biografi tokoh dari internet, menyiapkan lembar observasi kegiatan guru selama kegiatan pembelajaran, lembar observasi kegiatan siswa selama kegiatan pembelajaran. Pada setiap perencanaan peneliti juga mendiskusikannya dengan guru mitra Ibu Nunung Rohaeti, S.Pd. selaku kolaborator. Perencanaan-perencanaan dibuat sedemikian rupa dengan harapan tindakan dapat dilaksanakan dengan baik. Peneliti berdiskusi dengan kolaborator agar tidak ada hal-hal penting yang terlewatkan.

Pelaksanaan pembelajaran siklus pertama pertemuan pertama direncanakan hari Senin, tanggal 11 April 2011 jam kedua dan ketiga. Sedangkan pertemuan kedua direncanakan hari Kamis, tanggal 14 April 2011 jam ketiga dan keempat.

\section{2) Pelaksanaan Tindakan}

Tindakan pada siklus pertama terbagi dalam dua pertemuan. Pertemuan pertama dilaksanakan sesuai rencana pada hari Senin, tanggal 11 April 2011 jam kedua dan ketiga. Sebelum memulai pembelajaran guru terlebih dahulu mengatur siswa untuk duduk di tempatnya dengan baik. Setelah siswa siap mengikuti pembelajaran, guru mengucapkan salam kemudian ketua kelas memimpin doa. Guru melakukan presensi dan apersepsi. Pada 
pertemuan kali ini dua siswa tidak masuk kelas yaitu Mutiara Gita karena sakit dan Zaenal Arifin izin. Guru bertanya jawab dengan siswa tentang tokoh idola pada tes awal sebagai apersepsi. Siswa merasa kesulitan menceritakan tokoh idola karena belum tahu betul cara bercerita Guru menyampaikan rencana pelaksanaan pembelajaran yang akan dilaksanakan yang memuat tentang standar kompetensi,kompetensi dasar, indikator, tujuan pembelajaran, materi, metode, alat, media, dan penilaian. Standar kompetensi yaitu mengungkapkan pikiran, perasaan, informasi dan pengalaman melalui kegiatan menanggapi cerita dan bertelepon, kompetensi dasar menceritakan tokoh idola dengan mengemukakan identitas dan keunggulan tokoh, serta alasan mengidolakannya dengan pilihan kata yang sesuai, Indikator terdiri dari tiga yaitu mampu mengemukakan identitas tokoh, menentukan keunggulan tokoh dengan argumen yang tepat, serta mampu menceritakan tokoh idola dengan menyebutkan kelengkapan isi (identitas tokoh, keunggulan, alasan mengidolakannya) dengan pilhan kata, lafal, jeda dan intonasi, serta gerak/ mimik yang sesuai. Tujuan pembelajaran yaitu siswa dapat mengemukakan identitas tokoh, menentukan keunggulan tokoh dengan argumen yang kuat, serta menceritakan tokoh idola dengan menyebutkan kelengkapan isi (identitas, keunggulan, dan alasan mengidolakannya) dengan pilihan kata, lafal, jeda, intonasi, serta gerak/ mimik yang sesuai. media yang akan dipergunkan yaitu laptop, LCD dan gambar tokoh. Metode yang akan dipergunakan permainan bahasa. Penilain yang akan dilakukan yaitu lisan. Setelah itu guru menjelaskan tentang tujuan berbicara , metode berbicara, ciri-ciri pembicara yang baik, serta hal-hal yang perlu diperhatikan dalam berbicara khususnya menceritakan tokoh idola.

Setelah penjelasan siswa diberi kesempatan untuk bertanya, tetapi mayoritas siwa tidak bertanya. Hal ini dimungkinkan siswa sudah jelas atau takut karena yang mengajar bukan guru biasanya. Dalam menjawab pertanyaan pun siswa masih ragu-ragu dan harus dipancing oleh guru.

Pembelajaran dilanjutkan dengan meminta siswa untuk membuat dua kelompok besar dengan cara membagi siswa yang berada pada dua baris sebelah kanan dan dua baris sebelah kiri. Baris kanan dinamakan kelompok A dan baris kiri kelompok B. Selanjutnya, guru menjelaskan permainan yang akan dilakukan. Pertama dilakukan undian untuk menentukan kelompok mana yang akan tampil terlebih dahulu. Guru memperlihatkan gambar tokoh pahlawan nasional RA. Kartini dengan alasan bulan April adalah hari kelahiran RA Kartini seorang pahlawan wanita dari Jawa Tengah yang diharapkan telah dikenal oleh siswa dimungkinkan dapat menggali ide-ide siswa untuk bercerita. Giliran pertama yaitu kelompok A. Anggota kelompok A harus menyebutkan perihal gambar tersebut secara berurutan dalam bentuk kalimat yang gramatikal. Yang harus disebutkan adalah identitas, keunggulan, serta alasan mengidolakannya. Setiap siswa hanya boleh menyebutkan satu kalimat dengan harapan semua siswa mendapat giliran berbicara dan mau berbicara.

Kelompok B diminta mencermati kalimat- kalimat yang diucapkan anggota kelompok A dan meneliti kalimat-kalimat yang diucapkan tersebut gramatikal atau tidak, serta mencatat jumlah kalimat yang berhasil diucapkan baik yang gramatikal maupun yang tidak.

Giliran berikutnya kelompok B. Guru memperlihatkan gambar Pangeran Diponegoro, kemudian secara bergiliran anggota kelompok B menyebutkan identitas, keunggulan, serta alasan mengidolakannya. Setiap siswa hanya boleh menyebutkan satu kalimat dengan harapan semua siswa mendapat giliran berbicara dan mau berbicara.

Kelompok A diminta mencermati kalimat- kalimat yang diucapkan anggota kelompok B dan meneliti kalimat-kalimat yang diucapkan tersebut gramatikal atau tidak, serta mencatat jumlah kalimat yang berhasil diucapkan baik yang gramatikal maupun yang tidak. Setelah itu, bersama-sama menentukan kelompok yang mampu menceritakan tokoh idola dengan menyebutkan kalimat paling banyak dan gramatikal adalah pemenangnya. 
Kelompok A berhasil mengalahkan kelompok B dengan mengucapkan 11 kalimat sedang kelompok B hanya 9 kalimat.

Pertemuan kedua dilaksanakan pada hari Kamis tanggal 14 April 2011 jam ketiga dan keempat. Pembelajaran diawali dengan presensi dan apersepsi. Pada kegiatan ini satu siwa tidak masuk kelas yaitu Nilna Zariatul Ilmi sakit. Kegiatan siswa pada pertemuan ini adalah menceritakan tokoh idola dengan media menyebut gambar secara individu.

Hasil tes menceritakan tokoh idola pada siklus pertama, diketahui bahwa skor ratarata yang diperoleh siswa 14,26 nilai rata-rata yang diperoleh 71 . Jika dibandingkan dengan tes awal, skor rata-rata yang diperoleh siswa 12,9 nilai rata-rata 65. Pada siklus pertama terjadi peningkatan rata-rata nilai sebesar 6 poin atau sebesar $9 \%$ setelah dikenai tindakan.

\section{(1) Aspek kelengkapan isi}

Aspek kelengkapan isi pada tes awal skor rata-rata yang diperoleh siswa 2,7 nilai ratarata 66. Setelah diberi tindakan meningkat menjadi skor 2,9 nilai 73.

\section{(2) Pilihan kata}

Peningkatan nilai rata-rata aspek pilihan kata dari tes awal dibanding dengan siklus pertama yaitu tes awal skor rata-rata 2,8 nilai rata-rata yang diperoleh siswa 69 . Skor rata-rata yang diperoleh pada siklus pertama2,9 nilai 73 .

\section{(3) Pelafalan}

Skor rata-rata tes awal 2,5 nilai rata-rata aspek pelafalan pada tes awal 63. Pada siklus pertama nilai rata-rata yang diperoleh siswa 74, dengan skor rata-rata 2,9.

\section{(4) Jeda dan intonasi}

Pada aspek jeda dan intonasi hasil yang diperoleh siswa pada tes awal 66 skor ratarata 2,6. Nilai rata-rata yang diperoleh pada siklus pertama 72 , skor rata-rata 2,9.

\section{(5) Gerak/ mimik}

Nilai rata-rata yang diperoleh siswa pada tes awal 59, skor rata-rata 2,3. Pada siklus pertama setelah dikenai tindakan nilai rata-rata yang diperoleh siswa 65 , skor rata-rata 2,6 .

\section{3) Observasi}

Kegiatan observasi dilakukan oleh kolaborator beserta peneliti pada tiap pertemuan. Segala hal yang terjadi selama pembelajaran berlangsung dicatat oleh kolaborator dalam lembar observasi yang telah disiapkan oleh peneliti.

Pada saat pelaksanaan pembelajaran menceritakan tokoh idola dengan media menyebut gambar, dilakukan pengamatan dalam pedoman pengamatan dan catatan lapangan. Pelaksanaan pengamatan dan evaluasi ini meliputi dampak tindakan terhadap proses pembelajaran (keberhasilan proses) dan terhadap hasil pembelajaran.

\section{(a) Keberhasilan Proses}

Pada saat pelakasanaan kegiatan menceritakan tokoh idola dengan media menyebut gambar, siswa terlihat bersemangat. Meskipun masih ada siswa yang ramai sendiri,tetapi suasana masih kondusif. Pada waktu mendapat tugas menceritakan tokoh idola di depan kelas, siswa kelihatan antusias. Pada kesempatan ini siswa diberi kebebasan untuk memilih tokoh yang akan diceritakan. Tokoh yang diceritakan oleh siswa sangat bervariatif. Ada tokoh pahlawan, olahragawan, penyanyi, dan pemain film. Dengan gambar tokoh yang dipilih siswa memudahkan siswa menggali ide-ide untuk berbicara. Suasana kegitan belajar mengajar pun terasa bergairah dan menyenangkan.

Berdasarkan data hasil pengamatan, siklus pertama yang dilaksanakan dalam dua pertemuan menunjukkan bahwa sebagian aspek yang diamati dalam kategori baik. Pada pertemuan pertama perhatian siswa sudah baik, tetapi gairah belajar, keaktifann, proses 
belajar mengajar masih dalam kategori cukup. Pada pertemuan kedua kegiatan yang dilaksanakan adalah menceritakan tokoh idola. Perhatian, gairah belajar, keaktifan siswa , dan proses belajar mengajar sudah baik.

Peran guru dalam pembelajaran sangat memepengaruhi keberhasilan proses pembelajaran. Secara keseluruhan dalam siklus satu peran guru sudah baik. Tugas diberikan guru dengan jelas. Keterampilan guru dalam memantau perilaku siswa dan membimbing siswa untuk mengikuti pelajaran sudah dapat dinyatakan baik.

\section{b. Keberhasilan Hasil}

Keberhasilan siswa dalam menceritakan tokoh idola dapat dilihat dari hasil tes menceritakan tokoh idola setelah diberi tindakan pada siklus pertama dibandingkan dengan hasil yang diperoleh pada tes awal sebelum dikenai tindakan.

\section{4) Refleksi}

Berdasarkan pengamatan kolaborator dan peneliti terhadap tindakan yang sudah dilaksanakan dapat direfleksikan sebagai berikut.

(1) Sudah ada peningkatan hasil setelah dikenai tindakan, tetapi masih ada beberapa siswa belum dapat menceritakan tokoh idola dengan baik, terutama yang behubungan dengan intonasi, dan ekspresi.

(2) Media gambar yang disajikan kurang menarik perhatian siswa, mereka cenderung menyukai tokoh-tokoh zaman sekarang baik penyanyi, bintang film, olahragawan.

(3) Perlunya dilakukan siklus kedua

\section{Pelaksanaan Siklus 2}

\section{a) Perencanaan}

Siklus kedua direncanakan pelaksanaannya hari Senin, tanggal 18 April 2011 jam kedua dan ketiga. Sedangkan pertemuan kedua direncanakan hari Kamis, tanggal 21 April 2011. Dengan berpedoman pada hasil refleksi siklus pertama, maka pada Siklus kedua peneliti sepakat dengan kolaborator untuk menggunakan rencana pembelajaran yang sama dengan siklus pertama,tetapi media gambar yang disajikan berbeda. Gambar yang disajikan pada siswa lebih bervariatif dan diharapkan lebih disukai oleh siswa bahkan siswa dipersilahkan membawa gambar sendiri. Gambar tokoh diambil dari internet baik penyanyi, bintang film, olahragawan, ilmuwan. Sementara itu instrumen yang dipersiapkan sama dengan instrumen pada siklus pertama ditambah angket refleksi siswa terhadap pembelajaran menceritakan tokoh idola dengan media menyebut gambar.

\section{b) Pelaksanaan Tindakan}

Sesuai rencana, pertemuan pertama siklus kedua berlangsung pada hari Senin, tanggal 18 April 2011 jam kedua dan ketiga. Guru mengawali pembelajaran dengan mengucapkan salam. Pada jam pelajaran ini semua siswa masuk kelas. Guru mengulangi pembelajaran menceritakan tokoh idola dengan media menyebut gambar. Diawali dengan penjelasan tujuan berbicara, metode berbicara, ciri-ciri pembicara yang baik, hal-hal yang perlu diperhatikan ketika berbicara khususnya menceritkan tokoh idola. Kemudia guru memperilhatkan gambar Adly Fairuz, para siswa tanpa diminta langsung menyebutkan identitas, keunggulan, alasan mengidolakannya. Siswa lebih cepat dalam menyelesaikan tugas berbicara dimungkinkan mereka sudah mengenal sosok Adly Fairuz mungkin juga telah diperoleh pada pembelajaran membaca biografi tokoh pada pertemuan sebelumnya. Selanjutnya siswa diminta latihan untuk menceritakan tokoh idola masing-masing di depan kelas secara bergiliran. Setelah refleksi pembelajaran diakhiri dan siswa diberi tugas rumah untuk mempersiapkan tokoh idola yang akan diceritakan pada pertemuan berikutnya.

Pertemuan kedua hari Senin tanggal 21 April 2011. Kegiatan diawali mengucapkan salam menanyakan keadaan siswa, presensi dan apersepsi. Semua siswa masuk kelas. Pertemuan kali ini untuk penilaian secara individu. Dilakukan undian untuk menentukan urutan presentasi siswa. Guru menyediakan undian, salah satu siswa diminta mengambil 
undian untuk menentukan urutan pertama. Tokoh yang diceritakan bebas sesuai keinginan siswa. Selanjutnya siswa yang selesai tampil dipersilakan mengambil undian untuk urutan berikutnya. Pertemuan ditutup setelah dilakukan refleksi. Setelah itu siswa diminta mengisi angket refleksi pembelajaran.

\section{3) Observasi}

Kegiatan observasi dilakukan oleh kolaborator beserta peneliti pada tiap pertemuan. Segala hal yang terjadi selama pembelajaran berlangsung dicatat oleh kolaborator dalam lembar observasi yang telah disiapkan oleh peneliti.

Pada saat pelaksanaan pembelajaran menceritakan tokoh idola dengan media menyebut gambar, dilakukan pengamatan yang dideskripsikan dalam pedoman pengamatan dan catatan lapangan. Pelaksanaan pengamatan dan evaluasi ini meliputi dampak tindakan terhadap proses pembelajaran (keberhasilan proses) dan terhadap hasil pembelajaran .

\section{(a) Keberhasilan Proses}

Pada saat pelakasanaan kegiatan menceritakan tokoh idola dengan media menyebut gambar, siswa terlihat bersemangat. Meskipun masih ada siswa yang ramai sendiri, tetapi suasana masih kondusif. Pada waktu mendapat tugas menceritakan tokoh idola di depan kelas, siswa kelihatan antusias. Pada kesempatan ini siswa diberi kebebasan untuk memilih tokoh yang akan diceritakan. Tokoh yang diceritakan oleh siswa sangat bervariatif. Ada tokoh pahlawan, olahragawan, penyanyi, dan pemain film. Dengan gambar tokoh yang dipilih siswa memudahkan siswa menggali ide-ide untuk berbicara. Suasana kegitan belajar mengajar pun terasa bergairah dan menyenangkan lebih meningkat dibanding siklus pertama.

Peran guru dalam pembelajaran sangat mempengaruhi keberhasilan proses pembelajaran. Secara keseluruhan dalam siklus satu peran guru sudah baik. Tugas diberikan guru dengan jelas. Keterampilan guru dalam memantau perilaku siswa dan membimbing siswa untuk mengikuti pelajaran sudah dapat dinyatakan baik.

\section{b. Keberhasilan Hasil}

Keberhasilan siswa dalam menceritakan tokoh idola dapat dilihat dari hasil tes menceritakan tokoh idola setelah diberi tindakan pada siklus pertama dibandingkan dengan hasil yang diperoleh pada tes awal sebelum dikenai tindakan. Skor rata-rata yang diperoleh siswa 15,7, nilai rata-rata yang diperoleh siswa 78 berarti siswa telah tuntas belajar. Rata-rata nilai siklus kedua sudah melebihi KKM yang ditentukan yaitu 75. Peningkatan hasil siklus kedua dapat diketahui dengan perbandingan nilai rata-rata yang diperoleh dari tes menceritakan tokoh idola pada siklus kedua, kesatu, dan tes awal. Dari tabel 14 di atas, dapat diketahui skor rata-rata pada tes awal 12,9, siklus I 14,26. Nilai menceritakan tokoh idola dengan media menyebut gambar pada tes awal 65. Pada siklus I siswa memperoleh nilai ratarata 71 . Pada siklus I skor yang diperoleh 14,26 . Nilai rata -rata yang diperoleh 71 . Siklus II skor yang diperoleh siswa 15,7. Nilai rata-rata yang diperoleh siswa 78. Peningkata hasil tes awal ke siklus II adalah pada tes awal skor rata-rata yang diperoleh siswa 12,9, pada siklus II 15,7. Nilai rata-rata yang diperoleh pada tes awal 65, pada siklus II 78.

Peningkatan nilai rata-rata pada setiap aspek dapat dilihat sebagai berikut.

\section{(1) Kelengkapan isi}

Nilai rata-rata yang diperoleh siswa pada aspek kelengkapan isi saat tes awal sebelum diberi tindakan 66. Nilai rata-rata yang diperoleh pada siklus dua 90. Peningkatan aspek kelengkapan isi 24 atau $36 \%$.

\section{(2) Pilihan kata}

Nilai rata-rata aspek pilihan kata pada tes awal 69. Nilai rata-rata aspek pilihan kata pada siklus dua 83 . Peningkatan sebanyak 14 poin atau $20 \%$. 


\section{(3) Pelafalan}

Pada tes awal nilai rata-rata untuk aspek pelafalan 63. Pada siklus dua, nilai rata-rata yang diperoleh siswa pada aspek pelafalan 80. Peningkatan nilai rata-rata sebanyak 17 atau $26 \%$.

\section{(4) Jeda dan intonasi}

Jeda dan intonasi merupakan aspek penilaian menceritakan tokoh idola dengan media menyebut gamabar. Pada tes awal aspek jeda dan intonasi, nilai yang diperoleh siswa 66. Pada siklus dua siswa memperoleh nilai rat-rata 90. Terjadi peningkatan sebanyak 24 atau $36 \%$.

\section{(5) Gerak/mimik}

Aspek gerak dan mimik pada tes awal menceritakan tokoh idola dengan media menyebut gambar nilai rata-rata yang diperoleh siswa 59. Pada siklus dua nilai rata-rata yang diperoleh siswa pada aspek gerak dan mimik 65. Peningkata sebanyak 8 atau 14\%.

\section{(4) Refleksi}

Dalam diskusi antara peneliti dan kolaborator dalam siklus dua, ditarik kesimpulan bahwa tindakan-tindakan yang diberikan pada siklus dua telah meningkatkan keterampilan menceritakan tokoh idola yang cukup berarti. Peningkatan itu dapat dilihat dari proses pembelajaran menceritakan tokoh idola dengan media menyebut gambar, maupun dari segi hasil, yaitu nilai rata-rata menceritakan tokoh idola dengan media menyebut gambar mengalami peningkatan.

\section{PEMBAHASAN PENELITIAN}

\section{Informasi Awal Pengetahuan dan Keterampilan Siswa dalam Menceritakan Tokoh Idola.}

Informasi awal pengetahuan dan pengalaman siswa dalam bercerita dapat dilihat dari angket yang diberikan kepada siswa sebelum dilaksanakan tindakan kelas. Angket tersebut terdiri dari sembilan butir pertanyaan ( lihat tabel 2). Berdasarkan angket awal sikap siswa diperoleh informasi seperti berikut ini.

Sikap siswa terhadap pembelajaran bercerita yaitu sebanyak 22 siswa atau $63 \%$ dari keseluruhan siswa suka bercerita, sebanyak 5 siswa atau $14 \%$ menyatakan tidak suka bercerita, dan sebanyak 8 siswa atau 23\% menyatakan tidak tahu. Dari hasil tersebut dapat disimpulkan bahwa minat siswa terhadap pembelajaran bercerita perlu ditingkatkan.

Butir angket yang kedua berbunyi "Apakah Anda merasa keterampilan bercerita Anda sudahh baik? Pada butir ini semua siswa menyatakan merasa keterampilan berbicaranya belum baik.

Hanya lima siswa atau $14 \%$ dari keseluruhan siswa menyatakan menggunakan teknik tertentu dalam bercerita, 15 siswa atau $43 \%$ menyatakan tidak menggunakan teknik tertentu dalam bercerita, sedangkan 15 siswa atau $43 \%$ menyatakan tidak tahu. Dari hasil angket itu dapat disimpulkan bahwa sebagian besar siswa tidak menggunakan teknik tertentu dalam bercerita.

Tiga puluh dua siswa atau $91 \%$ menyatakan bahwa keterampilan bercerita perlu ditingkatkan, dan 3 siswa atau 9\% menyatakan tidak tahu. Kesimpulan yang bisa ditarik dari hasil angket butir ini adalah siswa perlu meningkatkan keterampilan berbicara.

Sebanyak 13 siswa atau 37\% siswa menyatakan sering mendapat tugas bercerita dari gurunya, 8 atau $23 \%$ siswa menyatakan tidak pernah mendapat tugas bercerita, dan sebanyak 14 siswa atau $40 \%$ menyatakan tidak tahu. Hal ini menunjukkan bahwa pembelajaran bercerita perlu mendapatkan porsi yang semestinya.

Dari 35 siswa, sebanyak 18 siswa atau 51\% menyatakan bahwa gurunya cukup menyenangkan dalam memberikan pelajaran bercerita, dua siswa atau $6 \%$ menyatakan gurunya tidak menyenangkan dan 15 siswa atau sebanyak $43 \%$ menyatakan tidak tahu. 
Berdasarkan hasil angket pada butir ini diperolah kesimpulan bahwa guru cukup menyenangkan dalam memberikan pelajaran bercerita.

Pada butir ketujuh, sebanyak 17 siswa atau $48 \%$ menyatakan gurunya cukup menarik dalam memberkan pelajaran bercerita, 3 siswa atau 9\% menyatakan tidak menarik, dan 15 siswa atau $43 \%$ menyatakan tidak tahu. Dengan demikian dapat disimpulkan bahwa dalam memberikan pelajaran bercerita guru cukup menarik.

Hanya 10 siswa atau 29\% menyatakan bahwa guru menggunakan media tertentu dalam pembelajaran bercerita, 13 siswa atau sebanyak 37\% menyatakan tidak, dan 12 anak atau 34\% menyatakan tidak tahu. Dari hasil angket butir ini menggambarkan bahwa menggunakan media dalam pembelajaran bercerita belum maksimal. Tiga puluh dua siswa atau 91\% siswa menyatakan ingin mendapat bimbingan guru dalam berceria, hanya 1 siswa atau 3\% menyatakan tidak, dan 2 orang siswa menyatakan tidak tahu. Kesimpulan dari hasil angket butir ini adalah sebagain besar siswa memerlukan bimbingan guru dalam pembelajaran bercerita. Siswa harus sering diberi latihan berbicara dengan menggunakan media.

Selain melalui angket, informasi awal keterampilan siswa dalam bercerita juga diperoleh dari kegiatan tes awal sebelum dilakukan tindakan. Pada tahap ini, siswa diberi tugas untuk menceritakan tokoh idola dengan menyebutkan identitas tokoh, keunggulan tokoh, serta alasan mengidolakannya dengan bahasa yang sesuai, lafal yang jelas, pilihan kata yang tepat, jeda, intonasi, volume, serta ekspresi yang sesuai. Masing- masing siswa diberi kebebasan untuk memilih tokoh yang diceritakan.

Waktu dua jam pelajaran yang diberikan oleh guru pada saat tes awal tidak dipergunakan secara maksimal oleh siswa. Banyak siswa yang menceritakan tokoh idola kurang sungguh- sungguh. Banyak siswa hanya menyebutkan nama tokoh dan profesinya saja. Mayoritas siswa masih belum total dalam bercerita. Masih ada siswa melafalkan kata kurang jelas, jeda belum, intonasi monoton, bahkan ada siswa yang volume suaranya hampir tidak terdengar, serta mayoritas siswa bercerita tanpa ekspresi yang sesuai.

Hasil tes awal sebelum dilakukan tindakan (lihat tabel 3) diketahui bahwa skor ratarata yang diperoleh belum sesuai dengan harapan. Nilai tertinggi pada tes awal mencapai 80 . Nilai terendah adalah 45 . Rata- rata hasil tes tersebut adalah 65. Rata-rata nilai tersebut menunjukkan bahwa keterampilan menceritakan tokoh idola siswa Kelas VI SD Negeri Kahuripan Bantarkalong masih dalam kategori cukup. Berdasarkan diskusi antara guru dan peneliti, jika dilihat dari sumber daya manusianya hasil tersebut dirasa masih kurang, mengingat siswa SD Negeri Kahuripan Bantarkalong adalah siswa-siswa yang mempunyai kecerdasan yang cukup tinggi. Jika dilakukan penggalian lebih dalam, serta potensi mereka dikembangkan dengan cara yang bervariasi dan inovatif, dimungkinkan siswa akan mampu menceritakan tokoh idola lebih baik lagi.

Dalam menceritakan tokoh idola ada aspek-aspek yang harus diperhatikan yaitu kelengkapan isi (identitas tokoh, keunggulan, alasan mengidolakannya), pilihan kata, (pelafalan kata secara jelas), jeda dan intonasi (pengaturan jeda, tinggi rendah nada, keras lemah suara, cepat dan lambat bercerita), serta gerak/mimik (kesesuaian antara ekspresi wajah, gerak, sikap, dan ucapan dengan isi cerita.

\section{a. Aspek Kelengkapan Isi}

Aspek kelengkapan isi meliputi tiga kriteria yaitu identitas tokoh, keunggulan, dan alasan mengidolakan. Hasil skor rata-rata yang diperoleh siswa 66. Hal ini menunjukkan bahwa bahwa keterampilan menceritakan tokoh idola aspek kelengkapan isi masih kurang karena di bawah ketuntasan yang ditetapkan yaitu 75 . 


\section{b. Aspek Pilihan Kata}

Aspek pilihan kata yang dimaksudkan disini adalah penggunaan pilihan kata yang sudah sesuai. Pada aspek ini diperoleh skor 97 dengan nilai 69. Hasil ini menunjukkan bahwa sebagian besar siswa telah penggunaan pilihan kata dengan baik.

\section{c. Pelafalan}

Aspek pelafalan skor siswa yang diperoleh siswa adalah 88 dengan nilai rata-rata 63. Banyak siswa yang melafalkan kata kurang jelas dan kurang tepat.

\section{d. Jeda dan Intonasi}

Pengaturan jeda dan intonasi termasuk di dalamnya keras/ lemah suara, dan cepat / lambat bercerita. Pada aspek ini jumlah skor yang diperoleh siswa 92. Nilai rata-rata 66. Hasil ini menunjukkan bahwa kemampuan siswa dalam menceritakan tokoh idola untuk aspek jeda dan intonasi masih perlu ditingkatkan.

\section{e. Gerak/mimik}

Apek gerak/ mimik yang dimaksudkan adalah kesesuaian ekspresi wajah, gerak, sikap, ucapan dengan isi cerita. Pada aspek ini skor yang diperoleh siswa adalah 82 dengan rata-rata nilai 59. Hasil itu menengarai bahwa siswa belum mampu berekspresi dalam menceritakan tokoh idola.

Berdasarkan angket awal dan hasil tes awal menceritakan tokoh idola, dapat disimpulkan bahwa selama ini pembelajaran menceritakan tokoh idola belum maksimal. Pembelajaran bercerita masih kurang, minat serta kemampuan siswa dalam menceritakan tokoh idola masih belum memadai.

\section{Pelaksanaan Tindakan Kelas Pembelajaran Menceritakan Tokoh Idola dengan Media Menyebut Gambar}

Pelaksanaan pembelajaran menceritakan tokoh idola dengan media menyebut gambar dilaksanakan dua siklus. Pembelajaran difokuskan pada kegiatan menceritakan tokoh idola.

Berdasarkan pengamatan yang telah dilakukan pada siklus satu dan siklus dua, semua aspek dalam pembelajaran menceritakan tokoh idola telah mengalami peningkatan. Aktivitas siswa dan guru sudah meningkat ke arah suasana pembelajaran yang aktif, inovatif, kreatif, dan menyenangkan. Siswa terlihat lebih bersemangat dalam mengikuti pembelajaran menceritakan tokoh idola yang dilaksanakan.

Pada siklus satu, pembelajaran menceritakan tokoh idola diawali dengan penyampaian materi mengenai menceritakan tokoh idola dengan media menyebut gambar. Kemudian latihan menceritakan tokoh idola dengan media menyebut gambar secara kelompok dan individu, dan diakhiri dengan tes menceritakan tokoh idola dengan media menyebut gambar secara individu.

Secara garis besar pada siklus satu telah mengalami peningkatan baik proses maupun hasil, tetapi peningkatan tersebut masih dirasa kurang. Baik proses maupun hasil, perlu diadakan perbaikan atau ditingkatkan. Dari segi proses, kekurangan masih terlihat pada penyampaian materi. Siswa masih terlihat kurang aktif dalam bercerita. Pada saat praktik menceritakan tokoh idola siswa masih kesulitan menceritakan tokoh idola karena mereka belum mengetahui identitas tokoh secara lengkap. Dilihat dari hasil, peningkatan nilai ratarata yang diperoleh siswa belum memuaskan.

Pada siklus dua, tindakan yang dilakukan hampir sama dengan siklus satu. Pada siklus dua dilakukan beberapa perbaikan mengenai hal-hal yang masih belum optimal pada siklus satu. Media yang digunakan pada pembelajaran siklus dua lebih banyak dan bervariatif dilengkapi dengan biografi tokoh. Hal ini untuk membantu siswa dalam praktik menceritakan tokoh idola. Agar hasil dapat maksimal siswa diberi kebebasan untuk memilih tokoh idola yang diceritakan. 
Aktivitas pada siklus dua banyak pengalami peningkatan. Perbaikan tindakan yang dilakukan berhasil mengoptimalkan pembelajaran menceritakan tokoh idola dengan media menyebut gambar. Pada saat praktik menceritakan tokoh idola, siswa terlihat lebih bersemangat dan lebih senang, karena yang mereka ceritakan adalah tokoh yang benar-benar disukai. Guru merasa senang karena melihat peningkatan yang terjadi pada siswa baik proses maupun hasil. Dari segi hasil, pada siklus dua telah mengalami peningkatan. Nilai rata-rata yang diperoleh siswa dalam pembelajaran menceritakan tokoh idola dengan media menyebut gambar lebih tinggi dibanding sebelumnya. Nilai rata-rata yang diperoleh siswa 78 . Peningkatan sudah dirasa optimal pada setiap aspek.

\section{a. Peningkatan Kualitas Proses}

Berdasarkan pengamatan mengenai berbagai aktivitas guru dan siswa dalam proses pembelajaran menceritakan tokoh idola dengan media menyebut gambar dari siklus satu sampai pada siklus dua telah mengalami peningkatan. Kekurangan yang masih ditemui dalam siklus satu mengenai kurangnya perhatian dan keaktifan siswa berhasil diatasi pada siklus dua.

Siswa memberikan respon positif terhadap pembelajaran menceritakan tokoh idola dengan media menyebut gambar. Mayoritas siswa merasakan manfaat media gambar dalam melaksanakan praktik menceritakan tokoh idola.

Peningkatan kualitas proses pembelajaran pada siklus satu dan dua dapat dilihat dalam tabel 11. Perhatian siswa, gairah belajar, keaktifan, dan proses belajar-mengajar secara keseluruhan dapat dikategorikan baik. Media menyebut gambar membantu guru dan siswa dalam pembelajaran menceritakan tokoh idola. Gambar- gambar yang disenangi siswa membuat siswa lebih bergairah dalam pembelajaran. Dengan media gambar siswa dapat menggali ide-ide untuk berbicara. Modal senang dan antusias menjadikan siswa aktif dan kreatif dalam belajar. Dengan demikian guru akan lebih mudah menumbuhkan motivasi dan minat siswa dan lebih mudah dalam mengelola dan mengontrol kelas. Peran guru dalam proses pembelajaran dapat dilihat pada tabel 12. Berdasarkan tabel tersebut, penyampaian materi, kejelasan tugas, pembimbingan, dan pemantauan terhadap siswa dikategorikan baik.

Berdasarkan angket refleksi yang diberikan pada akhir pembelajaran pada siklus dua (lihat tabel 17) diperoleh informasi bahwa pembelajaran menceritakan tokoh idola dengan media menyebut gambar membuat siswa senang, dan dapat meningkatkan keterampilan bercerita.

\section{b. Peningkatan Kualitas Hasil}

Peningkatan kualitas proses dalam aktivitas belajar mempunyai dampak positif terhadap peningkatan kualitas hasil pembelajaran. Peningkatan hasil pembelajaran menceritakan tokoh idola dengan media menyebut gambar dapat dilihat dari peningkatan hasil akhir siswa selama dua siklus pembelajaran. Dari kelima aspek dalam pedoman penilaian menceritakan tokoh idola menunjukkan adanya peningkatan. Berdasarkan hasil penelitian di atas, dapat diketahui rata-rata nilai menceritakan tokoh idola pada tes awal 65 . Nilai rata- rata pada siklus satu 71. Pada siklus dua nilai rata-rata yang diperoleh siswa adalah 78. Hal itu menunjukkan peningkatan nilai rata-rata. Dibandingkan dengan siklus satu niali rata-rata keterampilan menceritakan tokoh idola dengan media menyebut gambar pada siklus dua mengalami peningkatan sebanyak 7 poin atau $10 \%$, yaitu dari rata-rata 71 pada siklus satu, menjadi 78 pada siklus dua. Jika dibandingkan dengan nilai rata-rata pada tes awal, pada siklus dua mengalami peningkatan sebanyak 13 poin atau $16 \%$, yaitu dari rata-rata 65 pada tes awal

\section{1) Kelengkapan isi}


Nilai rata-rata nilai yang diperoleh siswa pada aspek kelengkapan isi saat tes awal sebelum diberi tindakan 66. Nilai rata-rata yang diperoleh pada siklus dua 90. Peningkatan aspek kelengkapan isi 24 atau $36 \%$.

\section{2) Pilihan kata}

Nilai rata-rata aspek pilihan kata pada tes awal 69. Nilai rata-rata aspek pilihan kata pada siklus dua 83 . Peningkatan sebanyak 14 poin atau $20 \%$.

\section{(3) Pelafalan}

Pada tes awal nilai rata-rata untuk aspek pelafalan 63. Pada siklus dua nilai rata-rata yang diperoleh siswa pada aspek pelafalan 80. Peningkatan nilai rata-rata sebanyak 17 atau $26 \%$.

\section{(4) Jeda dan intonasi}

Jeda dan intonasi merupakan aspek penilaian menceritakan tokoh idola dengan media menyebut gamabar. Pada tes awal aspek jeda dan intonasi, nilai yang diperoleh siswa 66. Pada siklus dua siswa memperoleh nilai rata-rata 90. Terjadi peningkatan sebanyak 24 atau $36 \%$.

\section{(5) Gerak/ mimik}

Aspek gerak dan mimik pada tes awal menceritakan tokoh idola dengan media menyebut gamba rnilai rata-rata yang diperoleh siswa 59. Pada siklus dua nilai rata-rata yang diperoleh siswa pada aspek gerak dan mimik 65. Peningkata sebanyak 6 atau 10\%.

Berdasarkan hasil penelitian tersebut, dapat diketahui peningkatan kualitas dalam menceritakan tokoh idola.

\section{Peningkatan Keterampilan Menceritakan Tokoh idola dengan Media Menyebut Gambar}

Pembelajaran menceritakan tokoh idola dengan media menyebut gambar bertujuan untuk mengetahui seberapa jauh keterampilan siswa dalam menceritakan tokoh idola dengan media menyebut gambar.

Penggunaa media gambar dalam pembelajaran menceritakan tokoh idola berhasil meningkatkan keterampilan siswa dalam bercerita. Peningkatan keterampilan menceritakan tokoh idola dengan media menyebut gambar dari awal sebelum diberi tindakan sampai setelah diberi tindakan pada siklus dua dapat dilihat pada tabel 15. Secara keseluruhan pada siklus II setiap aspek menceritakan tokoh idola mengalami peningkatan yang cukup signifikan.

Skor rata-rata keterampilan menceritakan tokoh idola dengan media menyebut gambar yang diperoleh pada tes awal adalah 12,9. Pada sklus I skor rata-rata yang diperoleh 14,26. Skor rata-rata yang diperoleh siswa pada siklus II adalah 15,7. Jika ditampilkan dalam bentuk histogram peningkatan hasil keterampilan menceritakan tokoh idola dengan media menyebut gambar adalah sebagai berikut.

\section{a. Peningkatan Skor Rata-rata Menceritakan Tokoh Idola dengan Media Menyebut Gambar pada Aspek Kelengkapan Isi}

Berdasarkan hasil pengolahan dapat diperoleh informasi bahwa pada aspek kelengkapan isi mengalami peningkatan baik pada siklus I maupun siklus II. Skor rata-rata yang diperoleh pada aspek kelengkapan isi pada tes awal 2,7. Skor rata-rata aspek kelengkapan isi pada siklus I 2,9. Skor rata-rata aspek kelengkapan isi pada siklus II 3,6. Dari informasi tersebut dapat disimpulkan bahwa pada siklus I terjadi peningkatan 0,2 atau $6,9 \%$. Peningkatan yang terjadi pada siklus II dari siklus I sebanyak 0,7 atau $24 \%$. Peningkatan skor rata-rata siklus II dari tes awal sebesar 0,9 atau $33 \%$.

b. Peningkatan Skor Rata-rata Menceritakan Tokoh Idola dengan Media Menyebut Gambar pada Aspek Pilihan Kata 
Skor rata-rata yang diperoleh pada tes awal 2,8. Pada siklus I skor rata-rata yang diperoleh 2,9. Peningkatan yang dicapai pada siklus I sebanyak 0,1 atau 3,6\%. Skor rata-rata yang diperoleh pada siklus II 3,3. Peningkatan skor rata-rata dari siklus I ke siklus II 0,4 atau 14\%. Peningkatan skor rata-rata dari tes awal sampai pada siklus II 0,5 atau sebesar $18 \%$.

\section{c. Peningkatan Skor Rata-rata Menceritakan Tokoh Idola dengan Media Menyebut Gambar pada Aspek Pelafalan}

Skor rata-rata yang diperoleh pada tes awal 2,5. Skor rata-rata yang diperoleh pada siklus I 2,9. Skor rata-rata meningkat 0,4 atau $16 \%$. Pada siklus II skor rata-rata yang diperoleh 3,2. Pada siklus II ini terjadi peningkatan dari siklus I sebanyak 0,3 atau 10\%. Peningkatan yang terjadi dari tes awal disbanding siklus II sebesar 0,7 atau $28 \%$.

d. Peningkatan Skor Rata-rata Menceritakan Tokoh Idola dengan Media Menyebut Gambar pada Aspek Jeda dan Intonasi

Skor rata-rata pada tes awal 2,6. Skor rata-rata pada siklus I dan II 2,9. Peningkatan skor ratarata dari tes awal sampai pada siklus II sebanyak 0,3 atau $16 \%$.

\section{e. Peningkatan Skor Rata-rata menceritakan tokoh idola dengan Media Menyebut} Gambar pada Aspek Gerak/Mimik

Skor rata-rata pada tes awal 2,3. Skor rata-rata pada siklus I 2,6. Pada siklus I diperoleh peningkatan skor rata-rata 0,3 atau $13 \%$. Peningkatan yang diperoleh dari siklus I dan siklus II sebanyak 0,1 atau 3,8\%. Peningkatan skor rata-rata dari tes awal sampai pada siklus II 0,4 atau $17 \%$.

Berdasarkan pembahasan peningkatan skor rata-rata yang diperoleh siswa pada setiap aspek pembelajaran menceritakan tokoh idola, dapat disimpulkan bahwa setelah diberikan serangkaian tindakan pada setiap siklus, secara keseluruhan keterampilan menceritakan tokoh idola mengalami peningkatan. Peningkatan tersebut dicapai dengan serangkaian tindakan yang diberikan pada siklus I dan II. Untuk memperoleh peningkatan tersebut diperlukan waktu dan proses yang cukup lama.

\section{KESIMPULAN}

Berdasarkan hasil penelitian dan pembahasan dapat disimpulkan bahwa media menyebut gambar dapat dimanfaatkan sebagai media pembelajaran menceritakan tokoh idola. Dengan media menyebut gambar terbukti mampu menggali ide-ide siswa untuk berbicara, khusussnya menceritakan tokoh idola. Gambar yang efektif untuk memotivasi siswa berbicara adalah gambar-gambar orang yang menjadi idola siwa, baik itu gambar artis, penyanyi, pelawak, ilmuwan, olahragawan, pahlawan dan lain-lain. Dengan gambar yang disenangi, siswa akan lebih aktif, kreatif dan senang dalam belajar sehingga hasilnya / prestasi meningkat.

\section{DAFTAR PUSTAKA}

Akhadiah, S. M.K, dkk. 1994. Bahasa Indonesia I. Jakarta : Departemen P dan K Aqib, Zainal. 2007. Penelitian Tindakan Kelas. Bandung: Yrama Widya. Arikunto, Suharsimi. 2007. Penelitian Tindakan Kelas. Jakarta: BumiAksara.

Depdikbud. Kurikulum 2004. Standar Kompetensi Mata Pelajaran Bahasa dan Sastra Indonesia. Jakarta: Depdikbud.

Depdikbud. 2005. Materi Pelatihan Teintegrasi Bahasa dan Sastra Indonesia.

Jakarta: Depdiknas.

Keraf, Gorys. 1997. Komposisi Sebuah Kemahiran Berbahasa. Jakarta: Nusa Indah. Moeleong. 1996. Metode Penelitian Kualitatif. Bandung: Rosdakarya. 
Nurgiyantoro, Burhan. 2008. Penilaian dalam Pengajaran Bahasa dan Sastra Indonesia.Yogyakarta: P3K

Tarigan, Henry Guntur. 1985. Berbicara Sebagai Suatu Keterampilan Berbahasa. Bandung: Angkasa. 